\title{
Język jako element rozszerzonego fenotypu. Przyczynek do aplikacji koncepcji rozszerzonego fenotypu w badaniach nad językiem ${ }^{1}$
}

\section{Language as an Element of the Extended Phenotype: A Contribution to the Application of the Extended Phenotype Concept in Linguistic Research}

Adrian P. Krysiak

(Poznań)

\author{
język to mój trzeci ulubiony organ \\ autor nieznany
}

\begin{abstract}
Dedykuję Krystynie Pieńczakowskiej, mojej babci, bez której to wszystko nie byłoby możliwe.
\end{abstract}

\begin{abstract}
This paper discusses evolutionary and neurobiological approaches to linguistic research. The role and significance of the co-evolution processes of language and the brain are highlighted. Thus language is regarded as a product of natural selection, shaped by the brain (but the influence is mutual). The author also indicates a possibility of applying the extended phenotype concept to the study of language. That original idea implies the perception of language as a neuromimesis-based phenotypic expression of the biological and cultural replicators outside the organism's body.
\end{abstract}

Autor pragnie podziękować dr. Pawłowi Nowakowskiemu z Instytutu Językoznawstwa UAM, Agnieszce Gorońskiej oraz anonimowemu recenzentowi za cenne uwagi mery toryczne. W tej wersji lista pozycji bibliograficznych została radykalnie skrócona, z czym autor się nie zgadza, ale na co musiał przystać. 


\section{Wprowadzenie}

Biologiczno-ewolucyjne spojrzenie na początki, rozwój, przetwarzanie i funkcje języka naturalnego zaowocowalo ujęciem zjawisk językowych w ramach metodologii nauk przyrodniczych oraz zastosowaniem teorii biologicznych w odniesieniu do języka, rozumianego jako jedna $z$ form komunikacji wewnatrz- i międzygatunkowej, związana z pamięcią i świadomościa (Gorzelańczyk/ Nowakowski 1999). Tak pojmowany złożony system znaków móg1 powstać w drodze stopniowego procesu ewolucji kumulatywnej przez dobór naturalny (Pinker/Bloom 1990). Neutralne mechanizmy ewolucji, takie jak dryf genetyczny, również mogly odegrać pewną rolę, chociaż naszym zdaniem niewielka, zważywszy na zlożoność systemu i koszty generowane przy jego nabywaniu i przetwarzaniu, a związane przede wszystkim $z$ emocjonalnymi reakcjami somatycznymi, przetwarzaniem neuronalnym i czasem poświęconym na akwizycję. Możliwe też, iż niektóre geny języka podlegaly presji selekcyjnej na skutek sprzężenia z niejęzykowymi genami, podlegajaccymi doborowi (ang. genetic hitchhiking).

Pozostając jednak przy koncepcji stopniowej ewolucji języka przez dobór naturalny, podkreślić należy, iż warunkiem koniecznym takiego procesu jest istnienie zmienności genetycznej pod względem danej cechy, co dla języka zostalo wykazane w Krysiak (2010b) Dodać należy, że zmienność genetyczna pod względem tej cechy (języka) mogla zostać znacznie ograniczona, gdyż ,,[e]wolucja w drodze doboru naturalnego niszczy genetyczna zmienność, na której bazuje" (Lewontin, cyt. za Dawkins 2003: 39). Jednocześnie trzeba pamiętać, że:

[z]dolności językowe sprzyjają przetrwaniu genów, które są za te zdolności odpowiedzialne, niezależnie od tego, czy geny te znajdują się w danym osobniku czy nie. Związane jest to z tym, że lepiej rozprzestrzeniają się geny, które umieją wywrzeć szerszy wplyw na środowisko (Gorzelańczyk) Nowakowski 1999). 
O szerokim wplywie takich genów traktowala będzie część druga artykułu. Pozostaje jeszcze kontrowersyjna kwestia daty powstania języka. Dobór naturalny potrzebowalby zapewne więcej niż 200-300 tysięcy lat, a już na pewno więcej niż 40-60 tysięcy lat, jak się czasem przyjmuje. Tak więc bardziej prawdopodobne wydaje się, że język powstal wcześniej, 2,5 (van Driem 2005), czy wręcz 5-6 milionów lat temu (Gorzelańczyk/Nowakowski 1999). Z drugiej strony badania Voighta et al. (2006) wskazują na względnie niedawną pozytywną selekcję ponad 250 genów czlowieka, co mogloby sugerować, iż 200-300 tysięcy lat to w tym wypadku wystarczająco dużo czasu ewolucyjnego. Gwoli ścisłości nadmienić należy, iż ze względu na gradualny, naturalny i względnie tylko progresywny charakter tego procesu (por. „efekt Czerwonej Królowej” w części 2), nie sposób ustalić w miarę dokładnej daty powstania języka.

\section{Korzyści selekcyjne}

Wśród korzyści, jakie przynosi większa sprawność komunikacyjna, często wymieniane sa: (i) manipulacja innymi osobnikami (Krebs/Dawkins 1984), związana między innymi z umiejętnością posługiwania się pojęciami abstrakcyjnymi (ii) odciążenie rąk i wzroku (w przypadku kanału shuchowo-głosowego) oraz, co za tym idzie, możliwość komunikacji na większe odległości oraz w warunkach ograniczonego dostępu światła (iii) możliwość uproszczenia zapisu engramów (Gorzelańczyk/Nowakowski 1999), co jest ważne, ponieważ przestrzeń ukladu nerwowego jest ograniczona, (iv) zwiększenie szans na znalezienie partnera seksualnego, szczególnie istotna w odniesieniu do niektórych gatunków (np. Homo sapiens), u których zachowania seksualne służą nie tylko prokreacji, ale przede wszystkim cementowaniu więzi międzyosobniczej (Krysiak 2010a), wreszcie (v) ksztaltowanie środowiska, w którym żyją osobniki (Gorzelańczyk/Nowakowski 1999) oraz (vi) wplyw na rozwój mózgowia (patrz niżej), co oddal już Williams pól wieku temu: 
Dobór prowadzący do zdobycia zdolności werbalnych jak najwcześniej w życiu osobnika doprowadził w wyniku allometrii mózg ludzki do takiego rozwoju, że co jakiś czas w populacji może pojawiać się Leonardo da Vinci (Williams, cyt. za Dawkins 2003: 54).

Może to być związane z ludzką neotenią i przedłużonym okresem opieki nad potomstwem, umożliwiającym nabycie konkretnego języka naturalnego. Jednocześnie wydaje się, że w przypadku ewolucji zdolności komunikacyjnych mamy do czynienia z procesem względnie tylko progresywnym. To zapewne mial na myśli Dennett, pisząc:

Coś, co na początku jest użytecznym, zapewniającym ci przewage luksusem, w szybko zmieniającym się świecie ma szanse stać się rzecza niezbędna. (...) Podobnie bylo w przypadku języka i postawy intencjonalnej. Pierwotny Dobry Trik szybko stał się praktyczną koniecznością ludzkiego życia, ponieważ nasi przodkowie coraz bardziej się socjalizowali i w coraz większym zakresie poshugiwali się językiem (Dennett 2008: 151).

Inaczej mówiąc, gdy dana klasa zachowań komunikacyjnych rozprzestrzeniła się w populacji, stając się strategią ewolucyjnie stabilną (w rozumieniu Maynard Smith/Price 1973), pojawił się „efekt Czerwonej Królowej” i reszta osobników po prostu musiała lepiej wykorzystywać system już istniejący, jak również dokonywać modyfikacji, by pozostać w wyścigu zbrojeńn ${ }^{2}$.

2 Zjawisko ewolucyjnego wyścigu zbrojeń zostalo zbadane i opisane przez biologów (Dawkins/Krebs 1979). Jedno z nowszych badań koncentruje się na koewolucji traszek rodzaju Taricha i pończosznika prążkowanego (Thamnophis sirtalis) (Hanifin et al. 2008). 


\section{Koewolucja języka i mózgu}

Obok teorii stricte adaptacjonistycznych (Pinker/Bloom 1990), ciekawą propozycją zdaje się koncepcja koewolucji języka i mózgu (np. Deacon 1997). Mimo, iż niektórzy jej zwolennicy (Christiansen/ Chater 2008) sceptycznie odnoszą się do wyjaśnień adaptacjonistycznych, to naszym zdaniem nie sposób zajmować się bardziej czy mniej złożonymi zjawiskami językowymi, ignorujac korzyści selekcyjne, jakie one przynosza. Sami sceptycy zdają się być tego świadomi, gdy określaja język mianem pasożyta, który przynosi korzyści swemu gospodarzowi (ang. nonobligate symbiant) ${ }^{3}$. Nasza propozycja jest pochodną tej hipotezy, mniej jednak radykalną. Jak zaznaczyliśmy, język stanowi przystosowanie do środowiska, ale jednocześnie wspóltworzy to środowisko. Tak więc nie tylko musial dostosować się do zastanych mechanizmów przetwarzania i uczenia się oraz do samego mózgu, ale też ksztaltowal ten mózg (Deacon 1997).

Dodatkowo, język „wymusza w dalszej kolejności eksplozję cywilizacyjna, kulturową i konieczność dostosowania się" (Gorzelańczyk/Nowakowski 1999). Przykladem tej eksplozji kulturowocywilizacyjnej może być rozwój pisma i wynalezienie alfabetu, co pozwalało na dokumentację zdarzeń, jak również przekazywanie informacji w czasie i na większe odległości, co stanowi przyczynek do aplikacji koncepcji rozszerzonego fenotypu (część 4).

Badania neurolingwistyczne potwierdzają, że obszary mózgu szczególnie zaangażowane w przetwarzanie języka, to pole Broki (44 i 45 obszar czołowy), pole Wernickego (22 obszar skroniowy), zakręt nadbrzeżny (ang. supramarginal gyrus) (40 obszar ciemieniowy) i zakręt katowy (ang. angular gyrus) (39 obszar ciemieniowy), zlokalizowane najczęściej w lewej półkuli (Sadowski 2001; Gleason/Bernstein Ratner 2005). Jednocześnie zwraca się uwagę na plastyczność mózgu w odniesieniu do przetwarzania języka, postulując mniejsze przywiązanie do łączenia danej funkcji języ-

Ponadto Deacon (1997) nazywa język ,wirusem”, a van Driem (2005) - ,organizmem". 
kowej z konkretnym obszaru mózgu oraz konieczność bardziej holistycznego ujęcia, w którym podkreśla się rolę sieci neuronowych wraz z ich wzajemnymi powiazaniami (ang. interconnected neural networks; neurocognitive networks). W podejściu tym wskazuje się na rolę polączeń korowo-korowych i korowo-prążkowiowo-korowych, obshugujących pamięć operacyjną, w przetwarzaniu języka (Krysiak 2010c). W szczególności magazyn fonologiczny lokalizuje się w okolicach lewego zakrętu nadbrzeżnego, a kontrolny system artykulacyjny w okolicach pola Broki ${ }^{4}$.

\section{Fenotyp rozszerzony}

Fenotyp rozszerzony zostal scharakteryzowany jako

[w]szelkie wplywy genu na otaczający świat. (...) [W]plyw, czyli efekt genu, rozumiany jest (...) jako jego odmienność od jego alleli. Tradycyjnie pojmowany fenotyp ogranicza się do efektów wywieranych $w$ ramach ciała, w którym mieści [się] dany gen. O wplywie rozszerzonego fenotypu warto mówić wtedy, gdy zmienia on - pozytywnie lub negatywnie - szanse przetrwania genu (Dawkins 2003: 336).

Początkowo wykorzystywana do wyjaśniania zjawiska budowli zwierzęcych (termitiery, tamy bobrów, gniazda altanników; por. Dawkins 2003: 254ff.), koncepcja rozszerzonego fenotypu bywa stosowana również w badaniach z tak różnorodnych dziedzin, jak parazytologia (Andersen et al. 2009; Bailey et al. 2009) , dendrologia (Stone/Cook 1998), czy medycyna (Lossos et al. 2005). Sam Dawkins pisal:

[M]arzy mi się, że dzięki koncepcji fenotypu rozszerzonego całe rozległe dziedziny biologii obejmujące komunikację

4 Magazyn fonologiczny i kontrolny system artykulacyjny są elementami pętli fonologicznej.

5 Logikę stojacą za pojęciem rozszerzonego fenotypu można bez problemu zastosować w przypadku większości badań tego typu, por. casus pasożytnicznych os (Libersat et al. 2009). 
Język jako element rozszerzonego fenotypu. Przyczynek do aplikacji koncepcji...

między zwierzętami, wytwory organizmów zwierzęcych. pasożytnictwo i symbiozę, ekologię zespołów, a wlaściwie wszystkie interakcje zachodzące między organizmami i w ich wnętrzu zyskają nowy wyraz (Dawkins 2003: 22f).

Tym bardziej zadziwia, że ten sam autor jako przyklad najdalszego dzialania na odleglość, które ,przychodzi mu do głowy”, podal „dystans między granicami bobrzego stawu a genami, których przetrwaniu to przystosowanie służy" (Dawkins 2003: 293).

Język (również w formie mówionej, ale zwlaszcza pismo) może oddzialywać na odległość znacznie większą niż kilka kilometrów ${ }^{6}$. Żeby jednak uznać go za przyklad rozszerzonego fenotypu, należy wykazać, iż (i) ma podloże genetyczne (występuje zróżnicowanie pod względem alleli; ale zobacz też niżej i przypis 9), (ii) zmienia szanse przetrwania genu. O genach języka już wspominaliśmy we Wprowadzeniu ${ }^{7}$ oraz w Krysiak (2010b), o znaczeniu przystosowawczym zaś w części 2 niniejszej pracy. Dodatkowo koncepcja koewolucji języka i mózgu wskazuje na kolejne korzyści selekcyjne.

Niczego nie zmienia prosta konstatacja, iż w przypadku ewolucji języka mamy do czynienia również z przekazem pozagenetycznym. czyli ewolucja kulturowa, nie tylko biologiczna. Na to odpowiedzieć można na dwa sposoby. Po pierwsze, dopóki jednostkami doboru są replikatory ${ }^{8}$ (por. Dawkins 2003: 112ff.), a dana cecha spelnia, mutatis mutandis, wymogi (i) oraz (ii) ${ }^{9}$, zasadnie jest mówić o rozszerzonym fenotypie. Po drugie, zarówno konstrukcje zwie-

6 Naszym zdaniem to wlaśnie działanie na większą odleglość i, przede wszystkim, odciążenie rąk w akcie komunikacji, moglo w znacznym stopniu przyczynić się do preferencji danego kanału i, w efekcie, do rozwoju mowy.

7 Więcej szczególowych informacji w: Vernes etal. (2008); Dediu/Ladd (2007) Pehniejsza lista pozycji bibliograficznych w Krysiak (2010b).

8 Van Driem (2005) zwraca uwagę na rolę replikatora kulturowego (memu), rozumianego nie jako jednostka naśladownictwa (ang. unit of imitation), ale jako jednostka neuroanatomiczna odnosząca się do znaku wg de Saussure'a: tj. neuronalny korelat treści oznaczanej wraz z neuronalną reprezentacją powiązanej z nim formy oznaczającej

9 Wymogi, w zmienionej postaci, brzmialyby następująco: (i) dana cecha (zjawisko) bazuje na zmienności allomorficznej replikatora, (ii) zmienia ona (cecha, zjawisko) szanse przetrwania replikatora. 
rzęce, jak i zachowania pasożytnicze czy różne formy komunikacji międzyosobniczej (i międzygatunkowej) są wynikiem ,kooperacji calych zestawów genów (sieci regulatorowe genów - GRN), regulowanych w sposób skoordynowany w komórkach i tkankach, z wplywami środowiskowymi w procesie rozwoju osobniczego" (Krysiak 2010b). Jest więc język wynikiem kooperacji GRN z wplywami środowiskowymi, czyli można go uznać za pewien element fenotypu zwierzęcia ${ }^{10}$.

Mimo iż „ewolucja kulturowa zawdzięcza ewolucji genetycznej swe powstanie i podstawy, ale posiada wlasny napęd" (Pulliam/ Dunford, cyt. za Dawkins 2003: 149), co w praktyce oznacza, iż oba procesy nie musza i najczęśsiej nie przebiegają tak samo, to zdecydowana większość zjawisk kulturowych ma biologiczne podloże, a ludzkie zachowanie (w dalszej perspektywie - kultura) moga być zmieniane i ksztaltowane przez czynniki stricte biologiczne ${ }^{11}$. Jednym z ciekawszych i lepiej udokumentowanych przykladów jest wplyw chorobotwórczego pierwotniaka Toxoplasma gondii, wywolującego toksoplazmozę. Żywicielem ostatecznym tego endopasożyta są kotowate, a pośrednim może być czlowiek. Występowanie toksoplazmozy w stadium utajonym szacuje się w populacjach ludzkich na 20-60\% (Lindová et al. 2006). W licznych badaniach (np. Lafferty 2006; Lindová et al. 2006) stwierdzono związki między występowaniem i natężeniem niektórych cech osobowościowych, zwiazanych zwlaszcza z zachowaniami społecznymi i interpersonalnymi, a toksoplazmozą utajoną. Autorzy prac podkreślająjednak, iż należy uwzględnić też inne, pozapasożytnicze, czynniki. Dodatkowe analizy potwierdzily istnienie różnic międzyplciowych w zakresie zmian zachowania osób zakażonych.

10 Gen na język (gen języka) to gen, którego zmiana strukturalna pociaga za sobą zmianę w cesze J (języku), przy założeniu niezmienności pozostałych czynników (Krysiak 2010b).

11 Christiansen/Chater (2008) stwierdzają wręcz, że cale fragmenty kultury Homo sapiens musiały dostosować się do ludzkich zdolności poznawczych, opartych na aktywności tkanki nerwowej. 


\section{Zakończenie}

Zaprezentowane tu podejście do języka jako, z jednej strony, fragmentu ludzkiej kultury oraz, z drugiej, dziedzictwa biologicznego czlowieka, pozwala spojrzeć na język w szerszym kontekście neuronalnych mechanizmów przetwarzania sekwencyjnego i kategoryzowania hierarchicznego oraz stanowi rozwiazanie, jak to nazywaja Christiansen/Chater (2008: 490f, 506ff.), „logicznego problemu ewolucji języka" (ang. logical problem oflanguage evolution). Zastosowanie teorii rozszerzonego fenotypu do rozważań nad językiem umożliwia przede wszystkim lepsze zrozumienie procesu koewolucji języka i mózgu, ale także wspiera samą koncepcję oraz dostarcza nowych danych odnośnie do oddziaływania replikatora poza cialo, w którym się znajduje. Korzyści, jakie można osiagną́ przez kontynuowanie wyznaczonej drogi sa więc interdyscyplinarne par excellence. W perspektywie dalszych badan szczególnie godne uwagi wydają się zagadnienia rozumienia języka jako formy pasożytnictwa oraz spojrzenie na zachowania komunikacyjne czlowieka z punktu widzenia memetyki. Zdaje się, iż w ujęciu memetycznym język naturalny należaloby traktować jako mempleks, zlożony $z$ fonemów, morfemów, słów i innymi syntagm w roli memów. To już jednak stanowi material na osobny artykuł.

\section{Bibliografia}

Andersen, Sandra B./Gerritsma, Sylvia/Yusah, Kalsum M./Mayntz, David/ Hywel-Jones, Nigel L./ Billen, Johan/Boomsma, Jacobus J./ Hughes, David P. (2009): ,The Life of a Dead Ant: The Expression of an Adaptive Extended Phenotype". American Naturalist 174, 424-433.

Bailey, Richard /Schönrogge, Karsten/Cook, James M./Melika, George/ Csóka, György/Thuróczy, Csaba/Stone, Graham N. (2009): „Host Niches and Defensive Extended Phenotype Structure Parasitoid Wasp Communities". PLoS Biology 7(8), e1000179. doi:10.1371/journal.pbio. 1000179

Christiansen, Morten H./Chater, Nick (2008): ,Language as Shaped by the Brain". Behavioral and Brain Sciences 31, 489-509. 
Dawkins, Richard (2003): Fenotyp rozszerzony. Dalekosiężny gen. Przel. J. Gliwicz. Warszawa: Prószyński i S-ka.

Dawkins, Richard/Krebs, John R. (1979): „Arms races between and within species". Proceedings of the Royal Society B: Biological Sciences 205 , 489-511.

Deacon, Terrence W. (1997): The symbolic species: The co-evolution of language and the brain. New York: W.W. Norton.

Dediu, Dan/Ladd, D. Robert (2007): „Linguistic tone is related to the population frequency of the adaptive haplogroups of two brain size genes, ASPM and Microcephalin". Proceedings of the National Academy of Sciences of the United States of America 104: 1944-1949.

Dennett, Daniel C. (2008): Odczarowanie. Religia jako zjawisko naturalne. Warszawa: Państwowy Instytut Wydawniczy.

Gleason, Jean Berko/Bernstein Ratner, Nan (2005): Psycholingwistyka. Gdańsk: Gdańskie Wydawnictwo Psychologiczne.

Gorzelańczyk, Edward J./Nowakowski, Pawel (1999): „Pamięć, świadomość i biologiczne podłoże pochodzenia języka". Investigationes Linguisticae 7, 161-172.

Hanifin, Charles T./Brodie, Edmund D. Jr./Brodie, Edmund D. III (2008) "Phenotypic Mismatches Reveal Escape from Arm-Race Coevolution". PLoS Biology 6(3), e60. doi:10.1371/journal.pbio.0060060

Krebs, John R./Dawkins, Richard (1984): „Animal signals: mind-reading and manipulation". [w:] Krebs, John R./Davies, Nicholas B. (red.) (1984): Behavioural Ecology: an evolutionary approach. Oxford: Blackwell Scientific Publications, 380-402.

Krysiak, Adrian P. (2010a): „Perspektywa bio- i neurolingwistyczna jako nowa determinanta w badaniach nad językiem". [w:] Mikołajczyk, Beata/ Taborek, Janusz/ Zabrocki, Wladyslaw (red.): Język w poznaniu 1. Poznań: Wydawnictwo Rys, 97-118.

Krysiak, Adrian P. (2010b): „(Poli)geny na język. Prolegomena do lingwistyki genetycznej”. Investigationes linguisticae XX, 33-39.

Krysiak, Adrian P. (2010c): „Korowe mechanizmy pamięci w ujęciu funkcjonalnym. Perspektywa biolingwistyczna" (w przygotowaniu).

Lafferty, Kevin D. (2006): „Can the Common Brain Parasite, Toxoplasma gondii, Influence Human Culture?" Proceedings of the Royal Society B: Biological Sciences 273, 2749-2755.

Libersat, Frederic/ Delago, Antonia/Gal, Ram (2009): „Manipulation of host behavior by parasitic insects and insect parasites". Annual Review of Entomology 54, 189-207. 
Lindová, Jitka/Novotná, Martina/Havlíček, Jan/Jozífková, Eva/Skallová. Anna/Kolbeková, Petra/Hodný, Zdeněk/Kodym, Petr/Flegr, Jaroslav (2006): „Gender Differences in Behavioral Changes Induced by Latent Toxoplasmosis". International Journal for Parasitology 36(14), $1485-1492$.

Lossos, Alexander/Soffer, Dov/Steiner-Birmanns, Bettina/Hassin-Baer, Sharon/Sadeh, Menachem/Sagi, Michal/Linetski, Eduard/Abramsky, Oded/Argov, Zohar/Rosenmann, Hanna (2005): „Extended Phenotype in the Transthyretin Tyr77 Familial Amyloid Polyneuropathy". European Neurology 53, 55-59.

Maynard Smith, John/Price, George R. (1973): „The Logic of Animal Conflict". Nature 246, 15-18.

Pinker, Steven/Bloom Paul (1990): „Natural language and natural selection". Behavioral and Brain Sciences 13(4), 707-784.

Sadowski, Bogdan (2001): Biologiczne mechanizmy zachowania się ludzi $i$ zwierzat. Warszawa: Wydawnictwo Naukowe PWN.

Stone, Graham N./Cook, James M. (1998): „The structure of cynipid oak galls: patterns in the evolution of an extended phenotype". Proceedings of the Royal Society B: Biological Sciences 265, 979-988.

van Driem, George (2005): „The language organism: The Leiden theory of language evolution". [w:] Minett, James W./Wang, William ShiYuan (red.): Language acquisition, change and emergence: Essays in evolutionary linguistics. Hong Kong: City University of Hong Kong Press, 331-340.

Vernes, Sonja C./Newbury, Dianne F./Abrahams, Brett S./Winchester, Laura/Nicod, Jérôme/Groszer, Matthias/Alarcón, Maricela/Oliver, Peter L./Davies, Kay E./Geschwind, Daniel H./Monaco, Anthony P./ Fisher, Simon E. (2008): „A functional genetic link between distinct developmental language disorders". The New England journal of medicine 359: 2337-2345.

Voight, Benjamin F./Kudaravalli, Sridhar/Wen, Xiaoquan/Pritchard, Jonathan K. (2006): „A map of recent positive selection in the human genome". PLoS Biology 4(3), e72. doi:10.1371/journal.pbio.0040072 